\title{
Impact of Blood Pressure on Presence or Absence of Chin Dimple
}

\author{
Muhammad Imran Qadir and Noor Arif* \\ Institute of Molecular Biology and Biotechnology, Bahauddin Zakariya University, Pakistan \\ *Corresponding author: Noor Arif, Institute of Molecular Biology and Biotechnology, Bahauddin Zakariya University, Pakistan
}

\begin{abstract}
Impact of blood pressure on dimple on chin was the objective of this study. Normal pressure of blood is crucial to life. Without the power that controls our blood to stream around the circulatory structure, no oxygen passed on through our tissues and organs. High pressure of blood also causes distinct syndromes. An estimate of 189 subjects partook in this survey. Subjects were undergraduate students in Bahauddin Zakariya University, Multan, Pakistan. Blood pressure was also examined by device. It was concluded from the survey that there was impact of systolic pressure of blood but there was no impact of diastolic pressure of blood on chin dimple.
\end{abstract}

Keywords: Systolic BP; Diastolic BP; Circulatory Strain; Dimple

\section{Introduction}

Normal pressure of blood is crucial to life. Without the power that controls our blood to stream around the circulatory structure, no oxygen passed on through our tissues and organs. Blood pressure is likewise fundamental since it conveys WBCs and antibodies that causes resistance. Blood itself conveys various different properties, including its temperature. It additionally conveys one of our barriers against tissue harm, the coagulating platelets that avert blood loss. Blood moves through our body as a result of a distinction in weight. Pressure of blood is most noteworthy toward the beginning of its voyage from our heart - when it enters the aorta - and it is least toward the finish of its adventure along continuously littler parts of arteries. That weight distinction is the thing that makes blood stream around our bodies. The state of the arteries influences blood pressure and stream and narrowing of the arteries can block the supply by and large, prompting hazardous conditions including stroke and heart assault [1]. Normal pressure of blood is $120 / 80 \mathrm{mmHg}$. High pressure of blood causes cardiovascular disorder. Hypertension ought to be treated at 130/80 as opposed to $140 / 90$. Pressure of blood has a day by day design. Circulatory strain is typically lower during the evening while people are in rest condition. The pulse begins to rise a couple of hours before a person wakes up. The pressure of blood keeps on ascending during the day and it is at peak in midafternoon. At that point in the late evening and night, pressure of blood starts dropping once more. Irregular pulse design, for example, hypertension during the night or promptly in the first part of the day, can imply that you have a medical issue. For unusual pulse, person can discuss with the specialist about the cause of unusual pulse or pressure of blood. Hypertension in people is a major issue today. Regularly, with increase in age, the pressure of blood also increases. Danger of hypertension starts to climb when men hit age 45 , despite the fact that it can happen in more youthful men. African-Americans will in general create it more in youth and have increasingly extreme hypertension. Obesity or a family ancestry of hypertension additionally builds hazard [2].

Hypertension is particularly risky, in light of the fact that individuals can have it for a considerable length of time without knowing. Numerous elements can prompt hypertension. Obviously, diet is a vital thing for controlling blood pressure. An excessive amount of salt, too little potassium, and a lot of liquor have all been found to expand the danger of hypertension. An excessive amount of pressure and too minimal physical action both increase the risk of more hypertension. In the event that the pressure of blood is very high, there might be sure symptoms to pay special attention to them as cerebral pain, chest torment, trouble in breathing, unpredictable heartbeat. Chin dimple is a y-molded depression on the jaw. The chin dimple is due to dominant genes present in the 
body. The chin dimple may be an inherited trait that is passed from parents to offspring or it can be appeared after birth. The dimple at the jaw occurs where the two bones fuses. The individual having this dimple seeks the attention of people. The person having chin dimple looks beautiful and this dimple look like in several shapes. Dimple on the chin is known as fovea mentalis. Dimples are visible indentations of the skin and a prevailing attribute. Anatomically, dimples might be brought about by varieties in the structure of some body tissue for instance muscles, connective tissues, skin and subcutaneous tissue [3]. Impact of blood pressure on chin dimple was the objective of this study.

\section{Materials and Methods}

Measurement of Blood Pressure: The instrument that is used to measure blood pressure is Sphygmomanometer. To start the measurement of pressure of blood, use an appropriate size of cuff on arm. The cuff should cover the $80 \%$ area of the upper part of arm. We measured the blood pressure of each student. The students were asked to sit on a comfortable chair and then the cuff was tightly wrapped around their arm. The device was set on and it automatically told the systolic and diastolic BP of the person.

Project Design: An estimate of 189 subjects partook in this survey. Subjects were undergraduates in Bahauddin Zakariya University, Multan, Pakistan. This survey was done to study the impact of blood pressure on chin dimple.

Statistical Analysis: M-STAT was used to carry out statistical analysis.

\section{Results}

Table 1: Impact of systolic pressure of blood on chin dimple (Mean \pm SD).

\begin{tabular}{|c|c|c|c|}
\hline Gender & $\begin{array}{c}\text { Chin dimple's } \\
\text { Presence }\end{array}$ & $\begin{array}{c}\text { Chin dimple's } \\
\text { Absence }\end{array}$ & $\boldsymbol{p}$ value \\
\hline Male & $122 \pm 12.86$ & $129.84 \pm 13.86$ & 0.08 \\
\hline Female & $111.6 \pm 13.7$ & $117.86 \pm 12.9$ & $0.03^{*}$ \\
\hline Combined & $114.65 \pm 14.18$ & $120.8 \pm 14.09$ & $0.01^{*}$ \\
\hline
\end{tabular}

$\mathrm{p}<0.05$ significant results.

Table 2: Impact of diastolic pressure of blood on chin dimple $($ Mean $\pm \mathrm{SD})$.

\begin{tabular}{|c|c|c|c|}
\hline Gender & $\begin{array}{c}\text { Chin dimple's } \\
\text { Presence }\end{array}$ & $\begin{array}{c}\text { Chin dimple's } \\
\text { Absence }\end{array}$ & p value \\
\hline Male & $70.33 \pm 13.64$ & $74.63 \pm 11.71$ & 0.33 \\
\hline Female & $73.41 \pm 12.57$ & $74.34 \pm 11.69$ & 0.72 \\
\hline Combined & $72.51 \pm 12.80$ & $74.41 \pm 11.65$ & 0.39 \\
\hline
\end{tabular}

$\mathrm{p}>0.05$ non-significant results.

Impact of systolic and diastolic blood pressure is given in Tables $1 \& 2$. In Table 1, results showed that females and combined (male and female) with systolic blood pressure had significant $p$ value that was less than 0.05 but $p$ value for male was higher than significant value but it was close to 0.05 that was significant. In Table 2 , all the results were non-significant. These results showed that there was no impact of diastolic pressure of blood on chin dimple.

\section{Discussion}

Recent studies have given an important advancement in research [4-11]. According to Rengin, Female Greek kids and youths running in age somewhere in the range of seven and fifteen years the nearness of cheek dimples was researched. There was anyway a noteworthy increment of dimples with age just as altogether higher quantities of uneven than symmetric expressions in all age groups. According to Carlene and Stephen, some examinations have evaluated the degree and conveyance of the blood pressure trouble around the world. The point of this examination was to evaluate the worldwide weight of illness identified with high blood pressure. Worldwide weight of infection owing to hypertension was assessed for gatherings as per age. Population affect divisions were determined with information for mean systolic blood pressure. 7.6 million unexpected losses and 92 million DALYs were ascribed to hypertension. About a large portion of this weight was in individuals with hypertension; the rest of in those with lesser degrees of hypertension.

\section{Conclusion}

It was concluded from the survey that there was impact of systolic pressure of blood on chin dimple but there was no impact of diastolic pressure of blood on chin dimple.

\section{References}

1. Trialists Collaboration BP ((2005) Effects of different blood pressurelowering regimens on major cardiovascular events in individuals with and without diabetes mellitus: results of prospectively designed overviews of randomized trials. Arch Intern Med 165(12): 1410-1419.

2. Lawes CM, Vander Hoorn S, Rodgers A (2008) Global burden of bloodpressure-related disease, 2001. The Lancet 371(9623): 1513-1518.

3. Daponte AP, Vienna A, Brant L, Hauser G (2004) Cheek dimples in Greek children and adolescents. International Journal of Anthropology 19(4): 289-295.

4. Qadir MI, Saba G (2018) Awareness about intestinal cancer in university student. Nov Appro in Can Study 1(3).

5. Qadir MI, Ghalia BA (2018) Awareness survey about colorectal cancer in students of M. Phil Biotechnology at Bahauddin Zakariya University, Multan, Pakistan. Nov Appro in Can Study 1(3).

6. Qadir MI, Rizvi M (2018) Awareness about thalassemia in post graduate students. MOJ Lymphology \& Phlebology 2(1): 14-16.

7. Qadir MI, Shahzad R (2018) Awareness about obesity in postgraduate students of biotechnology. Int J Mod Pharma Res 7(2): 14-16.

8. Qadir MI, Mehwish (2018) Awareness about psoriasis disease. Int J Mod Pharma Res 7(2): 17-18.

9. Qadir MI, Ishfaq S (2018) Awareness about hypertension in biology students. Int J Mod Pharma Res 7(2): 8-10.

10. Qadir MI, Saleem A (2018) Awareness about ischemic heart disease in university biotechnology students. Glo Adv Res J Med Medical Sci 7(3): 59-61.

11. Qadir MI, Javid A (2018) Awareness about Crohn's Disease in biotechnology students. Glo Adv Res J Med Medical Sci 7(3): 62-64. 
(CC) (i) This work is licensed under Creative

To Submit Your Article Click Here: $\quad$ Submit Article

DOI: $10.32474 /$ LOJPCR.2019.01.000109

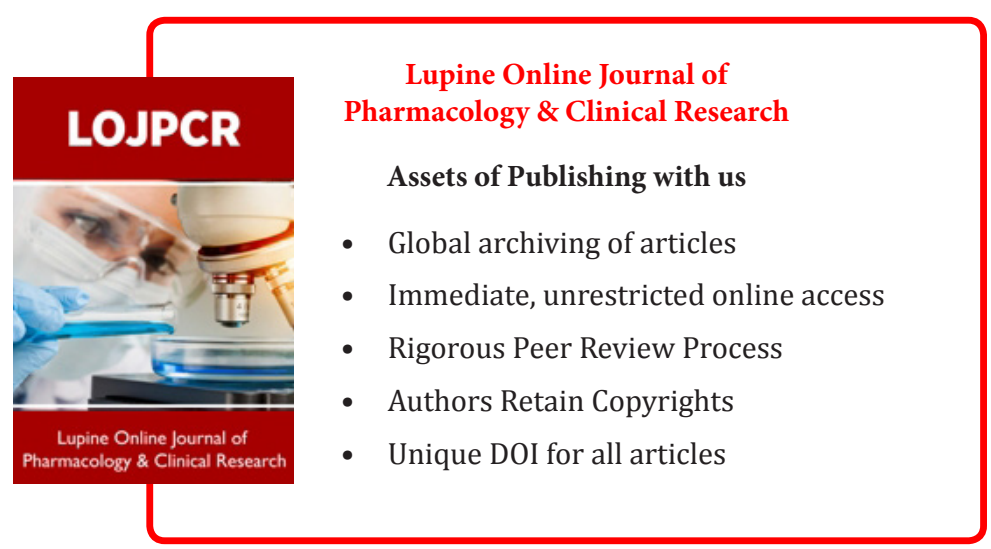

